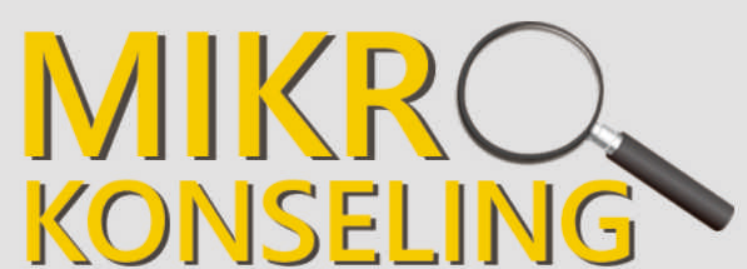

Konselor Handal, Profesional dan Bermartabat

Dengan Keterampilan ( Skill ) Konseling

Kegiatan mikro konseling adalah salah satu mata kuliah yang ditempuh oleh mahasiswa bimbingan konseling, dengan adanya buku ini diharapkan dapat menambah khazanah keilmuan, mempelajari, dan mengimplementasikan ilmu yang didapat di bangku perkuliahan untuk menjadi seorang guru bimbingan konseling yang terampil, profesional, dan bermartabat dalam melakukan kegiatan pelaksanaan layanan bimbingan konseling.

Buku ini membahas mengenai sistematika pelaksanaan kegiatan mikro konseling, pendekatan, dan keterampilan dalam melaksanakan konseling,serta perencanaan dan penilaian kegiatan mikro konseling. Semua kegiatan tersebut untuk menunjang calon guru bimbingan konseling supaya mempunyai keterampilan dan keahlian dalam melaksanakan kegiatan pelayanan bimbingan konseling. Dengan harapan kelak akan menajdi guru bimbingan konseling yang profesional, dan bermartabat.

Semoga buku ini menjadi panduan atau pedoman bagi mahasiswa atau calon guru bimbingan dan konseling untuk dapat melaksanakan kegiatan pelayanan bimbingan konseling.
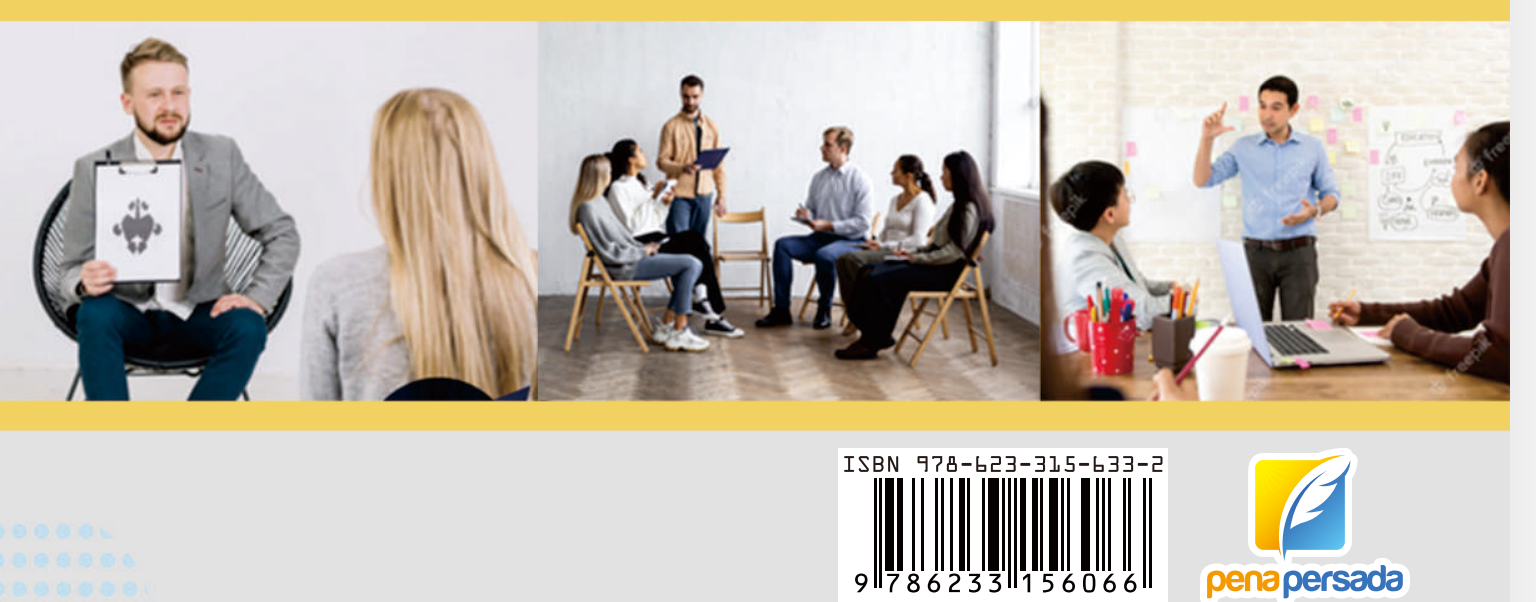

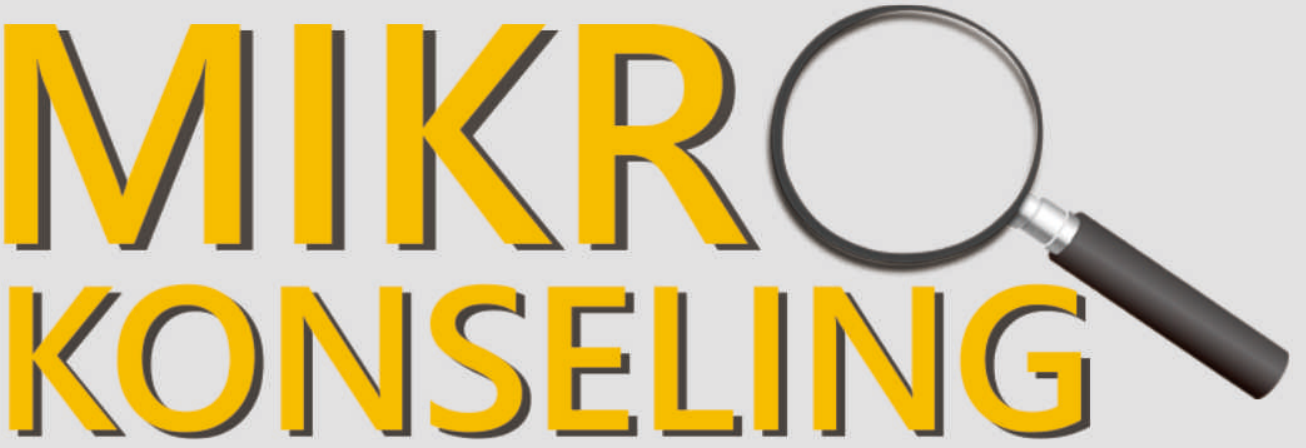

Konselor Handal, Profesional dan Bermartabat Dengan Keterampilan ( Skill ) Konseling
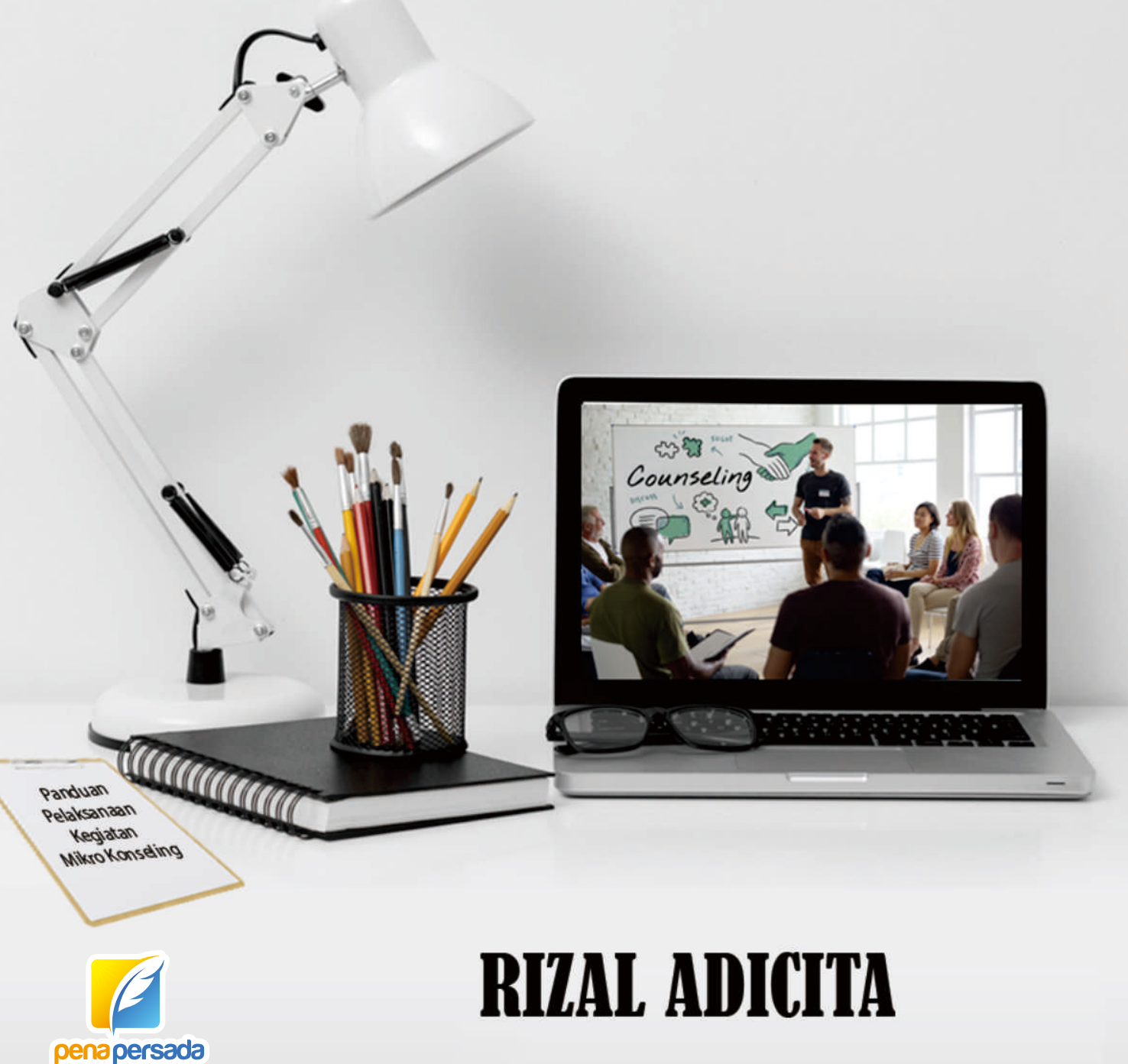

RILAL ADICITA 


\section{MIKRO KONSELING \\ Konselor Handal, Profesional Dan Bermartabat Dengan Keterampilan (Skill) Konseling}

Rizal Adicita

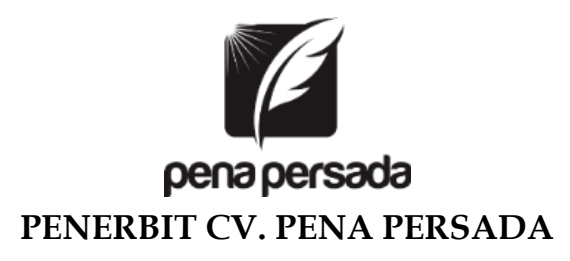




\section{MIKRO KONSELING \\ Konselor Handal, Profesional Dan Bermartabat \\ Dengan Keterampilan (Skill) Konseling}

Penulis:

Rizal Adicita

ISBN : 978-623-315-606-6

Design Cover :

Retnani Nur Briliant

Layout :

Eka Safitry

\section{Penerbit CV. Pena Persada}

Redaksi :

Jl. Gerilya No. 292 Purwokerto Selatan, Kab. Banyumas

Jawa Tengah

Email : penerbit.penapersada@gmail.com

Website : penapersada.com Phone : (0281) 7771388

Anggota IKAPI

All right reserved

Cetakan pertama : 2021

Hak Cipta dilindungi oleh undang-undang. Dilarang memperbanyak karya tulis ini dalam bentuk apapun tanpa izin penerbit 


\section{KATA PENGANTAR}

\section{Assalamualaikum Wr.Wb.}

Alhamdulillah,segala Puji syukur kehadirat Allah SWT yang telah melimpahkan rahmat, hidayah,serta inayah-Nya,sehingga Penulis dapat menyelesaikan, dan menerbitkan buku "pedoman pelaksanaan praktik, dan mikro konseling", buku panduan ini merupakan salah satu usaha untuk mewujudkan komitmen dalam membangun tradisi akademik khususnya untuk menjadi guide and reference bagi mahasiswa dan dosen pembimbing dalam rangka panduan, acuan, penyusunan, dan pelaporan dalam kegiatan pelaksanaan praktik, dan mikro konseling pada program studi bimbingan konseling.

Buku ini membahas mengenai pendahuluan, pelaksanaan kegiatan mikro konseling, pendekatan, keterampilan, perencaaan, penilaian, dan sistematika penyusunan pelaporan kegiatan praktik, dan mikro konseling.

Penulis mengetahui, dan sadar bahwa penulisan buku pedoman ini masih banyak kekurangan, dan sangat jauh kesempurnaan,karena mengingat pengetahuan dan kemampuan penulis yang masih terbatas.Maka dari itu,penulis mengharapkan kritik dan saran yang membangun,Sehingga pada saat penyusunan buku selanjutnya, bisa lebih baik lagi hasilnya. Meski masih banyak kekurangan atas penulisan buku ini, Penulis mengharapkan semoga buku ini mampu memberi sumbangsih, dan manfaat bagi pengguna (user), maupun Penulis pada khususnya.

Penulis juga menyadari,bahwa tanpa adanya bantuan, dukungan, dan kerjasama yang baik dari semua pihak, buku ini tidak akan terselesaikan dengan baik. Untuk itu, penulis mengucap kan terimakasih kepada semua pihak yang telah membantu dalam penyelesaian tugas merancang, membuat, dan menerbitkan buku ini.

Wassalamualaikum Wr.Wb.

Tegal, 3 Juli 2021

Penulis 


\section{SAMBUTAN KETUA STKIP NU KABUPATEN TEGAL}

Assalamualaikum Wr. Wb.

Alhamdulillah,segala Puji syukur kehadirat Allah SWT yang telah melimpahkan rahmat, hidayah,serta inayah-Nya, sehingga dapat terbitnya buku pedoman ini sebagai panduan, acuan, dan pelaporan kegiatan pelaksanaan praktik, dan mikro konseling.

Sejalan dengan pengembangan budaya akademik di lingkungan kampus Sekolah Tinggi Keguruan dan Ilmu Pendidikan Nahdlatul Ulama Kabupaten Tegal yang akan terus berbenah, dan bersinergis dalam mewujudkan komitmen, dan partisipasi aktif dengan semangat juang yang tinggi terhadap profesionalitas, dan pengabdian dalam kerangka mengembangkan khazanah keilmuan, khususnya dalam bidang bimbingan konseling.

Saya secara khusus menyambut pembuatan, dan penerbitan buku "pedoman pelaksanaan praktik, dan mikro konseling" ini sebagai sebuah langkah kerja nyata, dan tulus dalam membangun budaya akademik dalam rangka mengembangkan mutu akademik secara berkesinambungan. Keberadaan buku ini sangat membantu bagi citivas akademik program studi bimbingan konseling untuk meningkatkan kemampuan, keahlian, dan keterampilan dalam melaksanakan konseling.

Kami selaku pimpinan Sekolah Tinggi Keguuan dan Ilmu Pendidikan Nahdlatul Ulama Kabupaten Tegal mengucapkan terima kasih atas kerja keras, dan dedikasinya serta memberikan penghargaan yang setinggi - tingginya kepada penulis, dan semua pihak yang telah menyusun, membuat, dan menerbitkan buku pedoman ini. Tentunya buku ini tidak terlepas dari kesempurnaan, sehingga kritik, dan saran yang membangun dari semua pihak sangat kami harapkan. Semoga buku pedoman ini dapat bermanfaat, diterima, dan digunakan bagi civitas akademik program studi bimbingan konseling dalam melaksanakan praktik, dan mikro konseling. 


\section{DAFTAR ISI}

KATA PENGANTAR ............................................................... iii

SAMBUTAN KETUA STKIP NU KABUPATEN TEGAL ............... iv

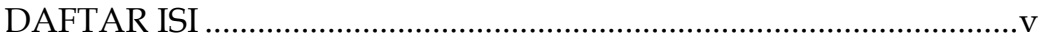

BAB I PENDAHULUAN ............................................................. 1

A. Pengertian Mikro Konseling ...........................................1

B. Dasar Pelaksanaan Kegiatan ...........................................2

C. Tujuan Kegiatan................................................................. 2

D. Syarat dan Bentuk Pelaksanaan Kegiatan........................3

E. Sifat Pelaksanaan Kegiatan ...........................................4

F. Sistem dan Tugas Pembimbingan................................... 5

BAB II PELAKSANAAN KEGIATAN MIKRO KONSELING ........7

A. Pengertian Mikro Konseling .........................................7

B. Tujuan Mikro Konseling................................................

C. Tempat Pelaksanaan Kegiatan........................................8

D. Waktu Pelaksanaan Kegiatan .........................................8

E. Tahapan Pelaksanaan Kegiatan Mikro Konseling ..........8

1. Tahap Orientasi Pelaksanaan Kegiatan .....................8

a. Orientasi Program Studi Mengenai Kegiatan Mikro Konseling..................................................9

b. Orientasi Pembimbing Mata Kuliah Mikro Konseling ............................................................. 9

c. Orientasi Mahasiswa Praktikan ............................9

2. Tahap Penugasan dan Pembagian Kelompok ...........9

3. Tahap Persiapan Simulasi Konseling .......................10

4. Tahap Pelaksanaan Simulasi Konseling ...................10

a. Tahap Identifikasi Kasus; ....................................10 
b. Tahap Identifikasi Masalah; ................................... 11

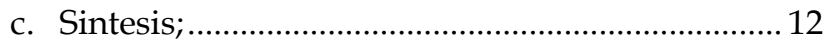

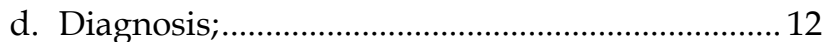

e. Prognosis; .................................................................. 12

f. Treatment; ............................................................... 13

g. Evaluasi, dan Tindak Lanjut................................... 13

5. Tahap Evaluasi dan Tindak Lanjut Pelaksanaan Kegiatan ..................................................................... 14

6. Tahap Pelaporan Pelaksanaan Kegiatan .................... 14

\section{BAB III PENDEKATAN, DAN KETERAMPILAN}

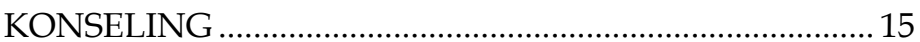

A. Pengertian Pendekatan dan Keterampilan

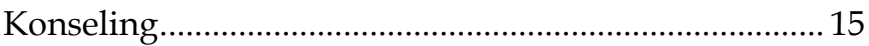

B. Tujuan Pelaksanaan Kegiatan Mikro Konseling............ 16

C. Pendekatan yang Dilaksanakan dalam Mikro

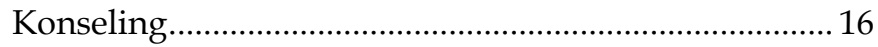

1. Konseling Berpusat Klien (Client-Centered Counseling)

2. Konseling Sifat, dan Faktor (Trait, and Factor Counseling)

3. Konseling Tingkah Laku (Behavioristic Counseling)

4. Terapi Rational Emotif (Rational Emotive

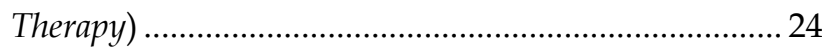

D. Keterampilan Dasar Konseling ....................................... 31

1. Penghampiran / Attending ............................................. 31

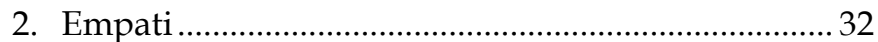

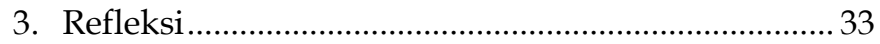

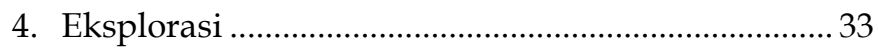


5. Menangkap Pesan Utama / Paraphasing ....................34

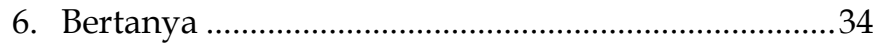

7. Dorongan minimal (Minimal Encouragement) ........35

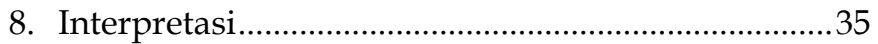

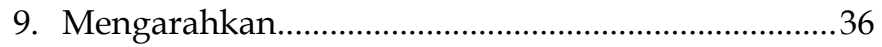

10. Menyimpulkan Sementara (Summarizing)..................36

11. Memimpin (Leading) .......................................................

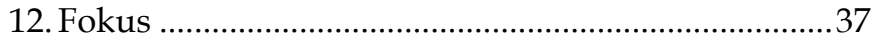

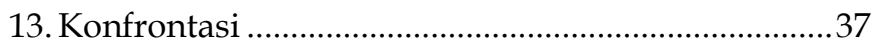

14. Menjernihkan (Clarifying) …………………………........3

15. Memudahkan (Facilitating) ...............................................

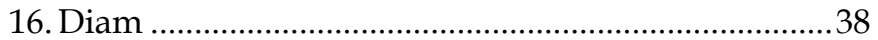

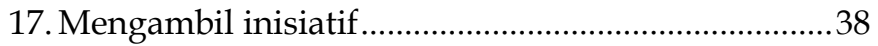

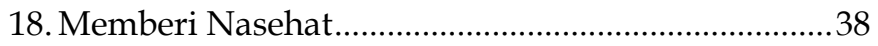

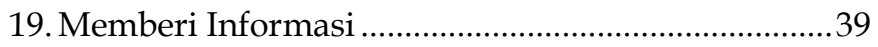

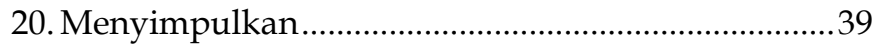

\section{BAB IV PERENCANAAN DAN PENILAIAN MIKRO}

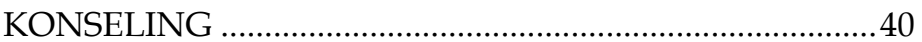

A. Perencanaan dan Penilaian Pelaksanaan Pelayanan

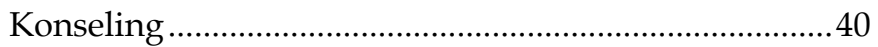

1. Pengertian .................................................................

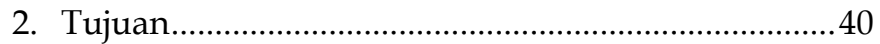

3. Format Penilaian .......................................................... 40

B. Kompetensi Praktikan dalam Pelaksanaan

Layanan Konseling..............................................................4

1. Layanan Klasikal...........................................................

a. Pengertian ............................................................

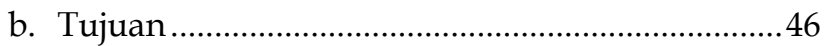


c. Format Penilaian ......................................................... 47

2. Layanan Bimbingan Kelompok .................................... 51

a. Pengertian ................................................................ 51

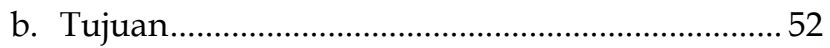

c. Format Penilaian ........................................................ 53

3. Layanan Konseling Kelompok ................................... 56

a. Pengertian ………………………………………........ 56

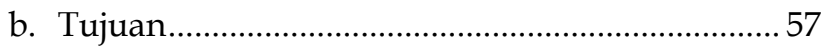

c. Format Penilaian ......................................................... 57

4. Layanan Konseling Individual .................................... 60

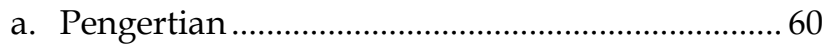

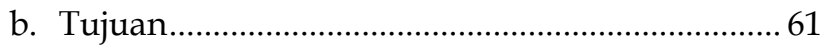

c. Format Penilaian ......................................................... 61

BAB V SISTEMATIKA PELAPORAN KEGIATAN PELAKSANAAN MIKRO KONSELING ............................. 70

A. Tata Cara Penulisan ………………………………............. 70

B. Sistematika Pelaporan ………........................................... 71

C. Halaman Cover Pelaporan Kegiatan Pelaksanaan Mikro Konseling ............................................................... 74

D. Halaman Pengesahan Pelaporan Kegiatan Mikro Konseling..................................................................... 75

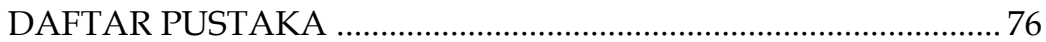




\section{BAB I \\ PENDAHULUAN}

\section{A. Pengertian Mikro Konseling}

1. Mata kuliah berbasis praktik yang wajib diikuti, dilaksanakan, dan dilaporkan dalam bentuk pelaporan oleh mahasiswa Program Studi Bimbingan, dan Konseling dapat mengimplementasikan pelaksanaan kegiatan pelayanan bimbingan, dan konseling secara terencana, tersusun, dan sistematis dibawah dosen pembimbing untuk memenuhi salah satu persyaratan kompetensi, keterampilan sebagai seorang konselor yang profesional dalam melaksanakan berbagai kegiatan pelaksanaan kegiatan pelayanan bimbingan konseling;

2. Implementasi dari pelaksanaan penerapan teori mikro konseling dalam kegiatan bermaksud menguasai berbagai pendekatan, teknik - teknik konseling baik dengan cara terpisah ( sendiri) maupun berkelompok supaya tercapainya keterampilan, dan kompetensi konselor secara menyeluruh, mampu menerapkan, dan mengintegrasikan teori, pendekatan, dan teknik konseling, bertujuan supaya menjadikan potensi manusia yang dapat dikembangkan (mahasiswa) yang memiliki dasar-dasar keilmuan, keahlian, dan kompetensi dalam pelaksanaan kegiatan layanan bimbingan konseling yang profesional, dan bermartabat;

3. Kegiatan pelaksanaan Mikro konseling dalam buku panduan ini pada dasarnya adalah bagian dari mata kuliah Program Studi, dan bersifat wajib untuk Program Studi Bimbingan Konseling dengan bobot 3 SKS dengan kode mata kuliah PBK3238. 


\section{B. Dasar Pelaksanaan Kegiatan}

1. Undang - Undang Nomor 20 Tahun 2003 tentang Sistem Pendidikan Nasional;

2. Undang - Undang Nomor 12 Tahun 2012 tentang Pendidikan Tinggi;

3. Peraturan Pemerintah Nomor 74 Tahun 2008 tentang Guru Bimbingan Konseling atau Konselor;

4. Permendiknas No 27 Tahun 2008 tentang Standar Kualifikasi Akademik Kompetensi Konselor;

5. Dasar Standarisasi Profesi Konseling yang dikeluarkan oleh Direktorat Jenderal Pendidikan Tinggi Tahun 2004 untuk memberi arah pengembangan profesi Bimbingan Konseling di sekolah, dan di luar sekolah;

6. STATUTA STKIP NU Kabupaten Tegal Tahun 2020;

7. Pedoman Akademik Program Studi Bimbingan Konseling STKIP NU Kabupaten Tegal;

8. Program Kerja Program Studi Bimbingan Konseling STKIP NU Kabupaten Tegal Tahun 2020;

9. SK Ketua STKIP NU Kabupaten Tegal No 001/Pan-MikroBK STKIPNU/X/2020 Tentang Pembentukan Panitia dan Tim Dosen Pembimbing Kegiatan Mikro Konseling.

\section{Tujuan Kegiatan}

Sebagai sarana menambah kazanah keilmuan bimbingan konseling, dan implementasi dari penguasaan pendekatan, teknik, keterampilan dan kompetensi seorang konselor yang wajib di ketahui, dan dipraktekan oleh mahasiswa praktikan sebagai seorang calon konselor profesional, dan bermartabat yang akan memberikan pelaksanaan pelayanan kegiatan konseling terhadap konseli melalui langkah-langkah kerja konseling diharapkan mahasiswa praktikan mampu mengimplementasikan layanan bimbingan konseling dalam bentuk layanan klasikal, layanan bimbingan kelompok, layanan konseling kelompok, dan layanan konseling individu. 
Keterampilan mahasiswa praktikan dalam pelayanan Bimbingan konseling untuk menambah keilmuan, pengalaman, mengimplementasikan, dan membuat bermacam - macam pilihan yang dapat diambil konseli untuk mengentaskan atau menangani masalah konseli dalam bentuk kehidupan efektif sehari-hari yang terganggu (KES-T), yaitu kehidupan pribadi, kehidupan sosial dengan teman sebaya, masyarakat, dan lingkungan sekitar. ${ }^{1}$

Disamping itu dengan adanya kegiatan ini diharapkan mahasiswa praktikkan mampu melihat, memahami, menggali potensi, bakat, minat, kondisi, kebutuhan, dan perkembangan peserta didik.

\section{Syarat dan Bentuk Pelaksanaan Kegiatan}

1. Syarat untuk dapat mengikuti mata kuliah mikro konseling adalah mahasiswa yang terdaftar, aktif sebagai mahasiswa di program studi bimbingan konseling pada semester VI sesuai dengan kurikulum yang sudah dibuat, ditetapkan atau telah menempuh, dan lulus mata praktikum konseling individual, praktikum bimbingan kelompok, praktikum konseling kelompok, dan telah menempuh 80 satuan kredit semester (sks), dimana jika mahasiswa telah memenuhi segala persyaratan diatas maka mahasiswa berhak mengambil mata kuliah mikro konseling;

2. Bentuk pelaksanaan kegiatan ini dengan cara mahasiswa melaksanakan praktik konseling individual dalam bentuk klien teman sebaya, klien remaja, dan klien dewasa yang untuk mengentaskan masalah di laboratorium konseling atau ruang kelas yang memenuhi standar pelaksanaan konseling individual;

Asosiasi Bimbingan dan Konseling Indonesia (ABKIN), Panduan Umum Pelayanan Bimbingan dan Konseling pada Satuan Pendidikan Dasar dan Menengah, 2013, hlm 11. 
3. Bentuk pelaksanaan kegiatan ini juga mencakup praktik melaksanakan pelayanan bimbingan kelompok, pelayanan konseling kelompok maupun pelayanan bimbingan klasikal sebagai bentuk dari implementasi teori yang sudah didapatkan ketika mendapatkan keilmuan, dan melaksanakan perkuliahan program studi bimbingan konseling;

4. Diakhir kegiatan akan adanya pelaporan pelaksanaan kegiatan mikro konseling yang tersusun secara rapi, sistematis sesuai dengan panduan penyusunan laporan kegiatan mikro konseling yang sudah dibuat oleh dosen pembimbing.

\section{E. Sifat Pelaksanaan Kegiatan}

1. Mata kuliah mikro konseling ini adalah mata wajib di laksanakan sebagai dasar mahasiswa menambah keilmuan, memiliki pengalaman yang berharga ketika dapat mengimplementasikan praktik kegiatan konseling, dan melakukan penyusunan pelaporan sesuai dengan pendekatan, teknik, keterampilan dasar, dan kompetensi konselor yang menyeluruh sebagai dasar mahasiswa praktikan sebelum mahasiswa menempuh kegiatan praktik pengalaman lapangan di lembaga atau instansi terkait;

2. Mata kuliah adalah perpaduan komponen pengetahuan, teori, teknik dan aplikasi pendekatan konseling secara menyeluruh, dan saling terkait satu dengan yang lainnya sebagai dasar untuk mahasiswa merasakan, dan berpengalaman dalam melakukan segala kegiatan pelayanan bimbingan konseling;

3. Sebagai mata kuliah berbobot praktik, keterampilan melaksanakan layanan konseling yang profesional maka kegiatan mikro konseling mempunyai mutu (bobot) 3 sks untuk program sarjana (S1) bimbingan, dan konseling ditempuh untuk mahasiswa yang telah mengikuti, dan lulus mata kuliah praktikum konseling individu, praktikum bimbingan kelompok, praktikum konseling kelompok. 


\section{F. Sistem dan Tugas Pembimbingan}

1. Sistem kegiatan mata kuliah ini menyeluruh, terpadu, dan berkesinambungan, terbimbing, dan terlaporkan dengan baik, dan sistematis dengan cara mahasiswa praktikan melaksanakan berbagai kegiatan pelaksanaan praktik kegiatan konseling yang dibimbing oleh Dosen pembimbing yang sudah di SK kan oleh Ketua STKIP NU Kabupaten Tegal yang berperan sebagai pembimbing, pengarah, fasilitator, dan pelapor kegiatan praktik mata kuliah ini;

2. Pembimbingan secara khusus dilaksanakan oleh pihak program studi bimbingan konseling sebagai penanggung jawab keilmuan, dan Dosen pembimbing yang diberikan SK oleh Ketua STKIP NU Kabupaten Tegal sebagai pembimbing diruang perkuliahan atau laboratorium yang memadai dengan tugas-tugas berikut:

a. Perencanaan atau planning, kegiatan mikro konseling ini supaya berhasil dengan baik perlu adanya perencanaan yang baik, dimulai dengan tujuan-tujuan apa yang ingin diharapkan, prosedur yang dipakai, metode yang digunakan, dan standar yang bermanfaat dalam memperoleh tujuan keberhasilan kegiatan ini;

b. Pengorganisasian atau organizing, penentuan kemampuan individu yang masih bisa dikembangkan (potensi) dalam pelaksanaan bentuk kegiatan mikro konseling ini ( mahasiswa praktikan), dan kegitan apa saja dapat dilaksanakan dan dikerjakan supaya mencapai arah yang dituju dalam kegiatan ini, penugasan tanggung jawab atau pendelegasian wewenang untuk melaksanakan tugasnya;

c. Pembagian tugas, orientasi kepada mahasiswa praktikan tentang tanggung jawab atau pekerjaan/ tugas yang diberikan, dan diselesaikan sebagai bahan dasar penilaian; 
d. Penyusunan bentuk kegiatan pelaksanaan layanan konseling sebagai bahan mahasiswa praktikan melaksanakan mikro konseling;

e. Membimbing, mengarahkan, memfasilitasi dan menyusun rancangan, melaksanakan, dan melaporkan hasil kegiatan;

f. Mendiskusikan hasil kegiatan mikro konseling bersama mahasiswa untuk perbaikan, tambahan khazanah keilmuan berlandaskan teori, pendekatan, dan teknik konseling, serta mahasiswa praktikan mampu implementasikan dalam kegiatan konseling;

g. Mengevaluasi atau controlling, penerapan cara atau langkah kerja yang sudah ditentukan untuk menjamin bahwa rencana yang sudah dibuat dan ditetapkan berlangsung dengan sepatutnya;

h. Membuat pelaporan berdasarkan sistematika laporan yang sudah diberikan sebagai bahan untuk melakukan penilaian hasil praktik mikro konseling. 


\section{BAB II \\ PELAKSANAAN KEGIATAN MIKRO KONSELING}

\section{A. Pengertian Mikro Konseling}

Serangkaian kegiatan pelaksanaan penguasaan keterampilan dasar konseling yang berlandaskan teori - teori atau keilmuan konseling dengan menggunakan pendekatan, teknik-teknik konseling dalam bentuk Co-counselor berupa simulasi atau praktik melaksanakan pelayanan konseling sebagai bentuk pelaksanaan kegiatan implementasi kompetensi dasar konseling telah dipelajari pada saat kegiatan perkuliahan yang mengkaji konseling. Kegiatan tersebut merupakan hasil dari implementasi aktivitas atau pelayanan konseling, dan melatih kompetensi pelayanan konseling secara profesional dalam berbagai layanan konseling, dan di laksanakan dalam berbagai bentuk kegiatan meliputi, perencanaan program, metode, pendekatan dan teknik serta sistematika pelaporan mikro konseling.

\section{B. Tujuan Mikro Konseling}

Tujuan dari kegiatan ini adalah melihat kemajuan mahasiswa praktikan mampu memahami materi perkuliahan ataupun teori yang telah dipelajari sebelumnya dalam berbagai mata kuliah konseling sebagai dasar untuk melaksanakan mikro konseling, meliputi:

1. Mampu mempraktekan keterampilan-keterampilan dasar komunikasi konseling;

2. Mampu mempraktekan beberapa pendekatan, dan teknik konseling dalam proses konseling sesuai dengan karakteristik masalah, dan karakteristik konseli; 
3. Mampu membuat konseli melakukan perubahan perubahan kecil terhadap perilaku yang merusak atau maladaptif;

4. Mampu menangani permasalahan konseli dalam bentuk kehidupan efektif sehari-hari yang terganggu.

\section{Tempat Pelaksanaan Kegiatan}

Pelaksanaan kegiatan ini akan dilakukan dalam ruang perkuliahan, atau di laboratorium konseling yang memadai yang menunjang keberhasilan melakukan konseling sebagai sarana untuk belajar, dan berlatih mahasiswa praktikkan untuk bekal melaksanakan kegiatan pelayanan konseling di lembaga formal seperti pelaksanaan pelayanan kegiatan konseling di sekolah.

\section{Waktu Pelaksanaan Kegiatan}

1. Kegiatan ini sudah diagendakan, direncanakan, dan akan dilaksanakan pada semester genap (VI) sesuai kurikulum program studi bimbingan konseling yang dibuat, dan tahun akademik pelaksanaan kegiatan mata kuliah mikro konseling;

2. Jadwal mengenai penugasan, dan praktik selanjutnya secara terperinci sudah diatur oleh panitia program studi maupun dosen pembimbing.

\section{E. Tahapan Pelaksanaan Kegiatan Mikro Konseling}

Pelaksanaan kegiatan ini sudah diatur melalui beberapa tahapan, yaitu dilaksanakan melalui:

\section{Tahap Orientasi Pelaksanaan Kegiatan}

Orientasi pelaksanaan kegiatan dilaksanakan dalam tiga tahap pelaksanaan kegiatan, yaitu: 
a. Orientasi Program Studi Mengenai Kegiatan Mikro Konseling

Orientasi ini bertujuan memberikan pemahaman, dan penjelasan secara umum mengenai mata kuliah mikro konseling

b. Orientasi Pembimbing Mata Kuliah Mikro Konseling

Orientasi kegiatan pelaksanaan ini bertujuan memberikan pemahaman, mengkaji, dan menyamakan persepsi antara kurikulum program studi dengan dosen pembimbing tentang prosedur, mekanisme, pola pelaksanaan, materi, dan penilaian yang akan dilaksanakan pada kegiatan mikro konseling;

c. Orientasi Mahasiswa Praktikan

Orientasi kegiatan pelaksanaan ini bertujuan:

1) Memberikan penugasan kepada mahasiswa praktikan mengenai kegiatan - kegiatan yang harus dilaksanakan sebagai bahan penilaian;

2) Memberikan panduan pelaksanaan, dan sistematika pelaporan kepada mahasiswa praktikkan, hal - hal apa saja yang akan dikerjakan, dan dipenuhi.

\section{Tahap Penugasan dan Pembagian Kelompok}

Pelaksanaan kegiatan ini disesuaikan dengan jumlah banyaknya mahasiswa praktikkan setiap angkatan yang memenuhi persyaratan untuk mengambil mata kuliah mikro konseling.

Pembentukan Co-counselor dibagi menjadi kelompok kecil sejumlah lima orang mahasiswa, yang berperan melaksanakan kegiatan layanan bimbingan klasikal, layanan bimbingan kelompok, layanan konseling kelompok, dan layanan konseling individual.

Tugas mahasiswa praktikkan dalam aktivitas kegiatan ini salah satunya dengan menjadi konselor, konseli, dan pengamat, mereka wajib melaksanakan keempat peran tersebut dalam berbagai pelaksanaan layanan bimbingan konseling. 


\section{Tahap Persiapan Simulasi Konseling}

Mahasiswa praktikkan harus membuat rencana pelaksanaan layanan konseling individual dalam bentuk Co-counselor dengan teman satu kelompok. Perencanaan pelaksanaan layanan konseling ini akan menggunakan salah satu pendekatan konseling atau teknik konseling. Melaksanakan layanan bimbingan kelompok, dan konseling kelompok, serta layanan klasikal. Rencana pelaksanaan semua bentuk kegiatan pelayanan harus dikonsultasikan dengan dosen pembimbing mikro konseling.

\section{Tahap Pelaksanaan Simulasi Konseling}

Supaya kegiatan ini berhasil mencapai tujuan yang sudah dibuat, dan ditetapkan. Sebelum melaksanakan kegiatan mikro konseling perlu adanya simulasi kegiatan pelaksanaan konseling sesuai dengan langkah - langkah yang telah disusun, meliputi:

\section{a. Tahap Identifikasi Kasus;}

Pada tahap ini merupakan tahap awal yang wajib dilalui, dan dilakukan mahasiswa praktikan supaya dapat menemukan konseli yang membutuhkan bantuan layanan bimbingan konseling. Langkah untuk dapat menemukan konseli yang akan melakukan konseling2:

1) Memanggil semua kemudian melakukan wawancara;

2) Meminta secara keseluruhan konseli bergiliran menceritakan permasalahan yang sedang dialami, dan menentukan skala prioritas permasalahan peserta didik yang membutuhkan pelayanan bimbingan konseling;

3) Menjaga ikatan kontak yang harmonis, tidak ada sekat diantara konselor dengan konseli;

Abin Syamsuddin Makmun, Psikologi Pendidikan, PT Rosda Karya Remaja, Bandung, 2003. 
4) Mengadakan sesuatu atau lingkungan yang baru yang dapat membangkitkan kembali kesadaran konseli terhadap permasalahan yang menimpanya;

5) Mengadakan pemecahan persoalan dengan melihat perolehan belajar siswa, sehingga bisa ditemukan tinggi rendah, dan klasifikasi kesukaran belajar yang dialami siswa;

6) Melakukan analisis sosiometri, dengan langkah ini diharapkan dapat diketahui konseli yang disangka menanggung permasalahan dalam hal penyesuaian lingkungan sosial.

\section{b. Tahap Identifikasi Masalah;}

Dalam tahapan kegiatan ini diharapkan mahasiswa praktikan dapat memahami kesulitan, jenis, karakteristik kesulitan yang ditanggung oleh konseli. Dalam proses pembelajaran, kesulitan konseli berkaitan dengan aspek: substansial (material), structural (fungsional), behavioral, dan personality. ${ }^{3}$

Untuk mengidentifikasi masalah, dan kasus siswa (konseli) salah satu caranya menggunakan aplikasi Angket Kebutuhan Peserta Didik (AKPD). Instrumen ini memberikan gambaran objektif mengenai kebutuhan atau kesulitan peserta didik atau konseli berdasarkan bidang bimbingan pribadi, sosial, belajar, dan karir. Untuk menganalisis keterkaitan antara tugas perkembangan dengan Standar Kompetensi Kemandirian Peserta Didik (SKKPD) mengacu dari tugas perkembangan yang akan dicapai oleh peserta didik atau konseli, dan standar kompetensi lulusan (SKL). ${ }^{4}$

Mengenai hal diatas dalam bidang pribadi adalah dasar kehidupan beragama, dasar berperilaku sesuai dengan etika, perubahan emosi yang matang,

Akhmad Sudrajat, Mengatasi Masalah Melalui Layanan Konseling Individual, Paramitra Publishing, Yogyakarta, 2013, hlm 29.

Andori, Aplikasi Angket Kebutuhan Peserta Didik (AKPD), Paramitra Publishing. 